\title{
29. DATA REPORT: PROVENANCE ANALYSIS OF QUATERNARY SANDS AND SANDSTONES FROM CASCADIA MARGIN ${ }^{1}$
}

\author{
Jan H. Behrmann, ${ }^{2}$ Peter Bauer, ${ }^{2}$ and Achim Kopf ${ }^{2}$
}

\begin{abstract}
Detrital framework modes have been determined for the sand fraction of Quaternary terrigenous clastic sediments from the Cascadia accretionary wedge. The sands and sandstones analyzed are moderately quartz-dominated, with smaller fractions of both feldspars and lithic fragments. Triangular discrimination plots indicate provenance from a recycled-orogenic crust, perhaps with a contribution from a deeply dissected magmatic arc. The composition of the modern active continental margin of British Columbia, Washington, and Oregon is reflected well by sandstone composition in the Cascadia trench-forearc system.
\end{abstract}

\section{INTRODUCTION}

The mineralogy of a provenance area and its plate-tectonic setting strongly influences sandstone compositions (e.g., Dickinson and Suczek, 1979; Dickinson et al., 1983). In continental-margin settings, sand detrital modes can be sensitive indicators of plate-tectonic processes affecting the margin itself (e.g., Marsaglia, 1991; Marsaglia et al., 1995), and reflect protracted phases of arc magmatism, lulls in volcanic activity, or major continental uplift and subsequent erosion. In their study of Phanerozoic North American sandstones, Dickinson et al. (1983) showed that Neogene onshore occurrences in the Pacific northwest of the United States and Canada are clearly magmatic-arcrelated, with recycled orogenic sands and transitional continental suites north of the Queen Charlotte fault and south of the Mendocino transform faults, respectively (see Fig. 1A).

We report modal composition data of Pleistocene framework-supported turbiditic sands and sandstones from the Cascadia accretionary prism, and we attempt to make inferences about their provenance and the tectonic context of the source areas. Scientific offshore drilling in the Cascadia accretionary prism during Leg 146 of the Ocean Drilling Program (ODP) (Westbrook, Carson, Musgrave, et al., 1994) was located in the North American forearc above the downgoing Juan de Fuca Plate (Fig. 1B). Sites 888-890 were drilled off the coast of Vancouver Island and to the north of the Nitinat Fan. Sites 891 and 892 were drilled off the coast of Oregon to the south of the Astoria Fan. The penetrated sediments principally consist of abyssal-plain clays and silts, and of middle-to-outer-fan hemipelagic turbidites and mass-flow deposits. For a detailed description of lithostratigraphy and facies, see Westbrook, Carson, Musgrave, et al. (1994). Samples analyzed in this study came from Sites 889,891 , and 892 .

\section{METHODS}

Framework modal compositions were determined from 16 Leg 146 sand samples (out of a batch of 80 ) that are well sorted and sufficiently free of matrix to allow provenance analysis. Sample identi-

'Carson, B., Westbrook, G.K., Musgrave, R.J., and Suess, E. (Eds.), 1995. Proc. ODP, Sci. Results, 146 (Pt. 1): College Station, TX (Ocean Drilling Program).

'Institut für Geowissenschaften und Lithosphärenforschung, Universität Giessen, Senckenbergstrasse 3, D-35390 Giessen, Federal Republic of Germany. fications and results of the modal analysis are given in Tables 1 and 2 . Counting was restricted to monocrystalline quartz $(\mathrm{Qm})$, polycrystalline quartz $(\mathrm{Qp})$, plagioclase $(\mathrm{P})$ and orthoclase $(\mathrm{K})$ feldspars, and lithic fragments derived from sediments (Ls) or volcanics (Lv). The other parameters shown in Table 1 are total quartz $(\mathrm{Q}=\mathrm{Qm}+\mathrm{Qp})$, total feldspar $(\mathrm{F}=\mathrm{K}+\mathrm{P})$, lithic fragments $(\mathrm{L}=\mathrm{Ls}+\mathrm{Lv})$, and total lithics $(\mathrm{Lt}=\mathrm{L}+\mathrm{Qp})$. Lithic fragments of metamorphic rocks appear under the Ls and Lv categories. Where detected, however, their proportion is small. Sand-sized grains of bioclastic calcite, and other terrigenous and volcanic minerals were not counted. Thin sections were not stained, but ambiguities in feldspar identification were avoided by using conoscopic techniques where necessary.

The samples were freeze-dried and then impregnated with epoxy resin. Petrographic thin sections were cut in orientations parallel to the core axis (i.e., perpendicular to bedding) and described for their mineralogical composition (see below). Point counting was carried out on a rectangular grid with an equal spacing of $2 \mathrm{~mm}$. The field of view at each station was $1.2 \mathrm{~mm}$ in diameter, and within this field of view all sand-sized ( 0.06 to $2 \mathrm{~mm}$ ) grains were counted and classified. Depending on mean grain size, between 81 and 1911 grains were counted per sample. This counting procedure introduces a bias towards fine grain sizes (cf. Ingersoll et al., 1984). However, we feel that this does not constitute a major problem in the well-sorted and generally fine- to medium-grained sand and sandstone samples chosen for the analysis.

\section{SAND AND SANDSTONE PETROGRAPHY}

The sands and sandstones analyzed varied between arkosic to quartzose, with a minor component of lithic fragments. The quartz grains are subrounded, often polycrystalline, and have sizes ranging from 0.07 to $2 \mathrm{~mm}$ with a maximum at sizes between 0.1 and $0.4 \mathrm{~mm}$. Plagioclase and potassic feldspar occur in variable amounts, generally with angular grain shapes. Plagioclase commonly shows polysynthetic twinning. Most of the potassic feldspar is microcline. Carbonates occur as bioclasts, as authigenic concretions or as cement of extensional veins and fractures (Kopf et al., this volume). Although the total amount of carbonate is in the $1 \%-10 \%$ range in some of the samples analyzed it was ignored in the counting procedure, as the concentration of carbonate may be dominantly an effect of diagenesis. Accessory minerals are clinopyroxene and amphiboles, detrital micas (muscovite and biotite in the case of Sample 891B-14X$1,66-70 \mathrm{~cm}$ ), pyrite, and $\mathrm{Fe}$-oxides. Siliceous microfossil fragments, mainly diatoms, also occur. Lithic fragments are well-rounded or 


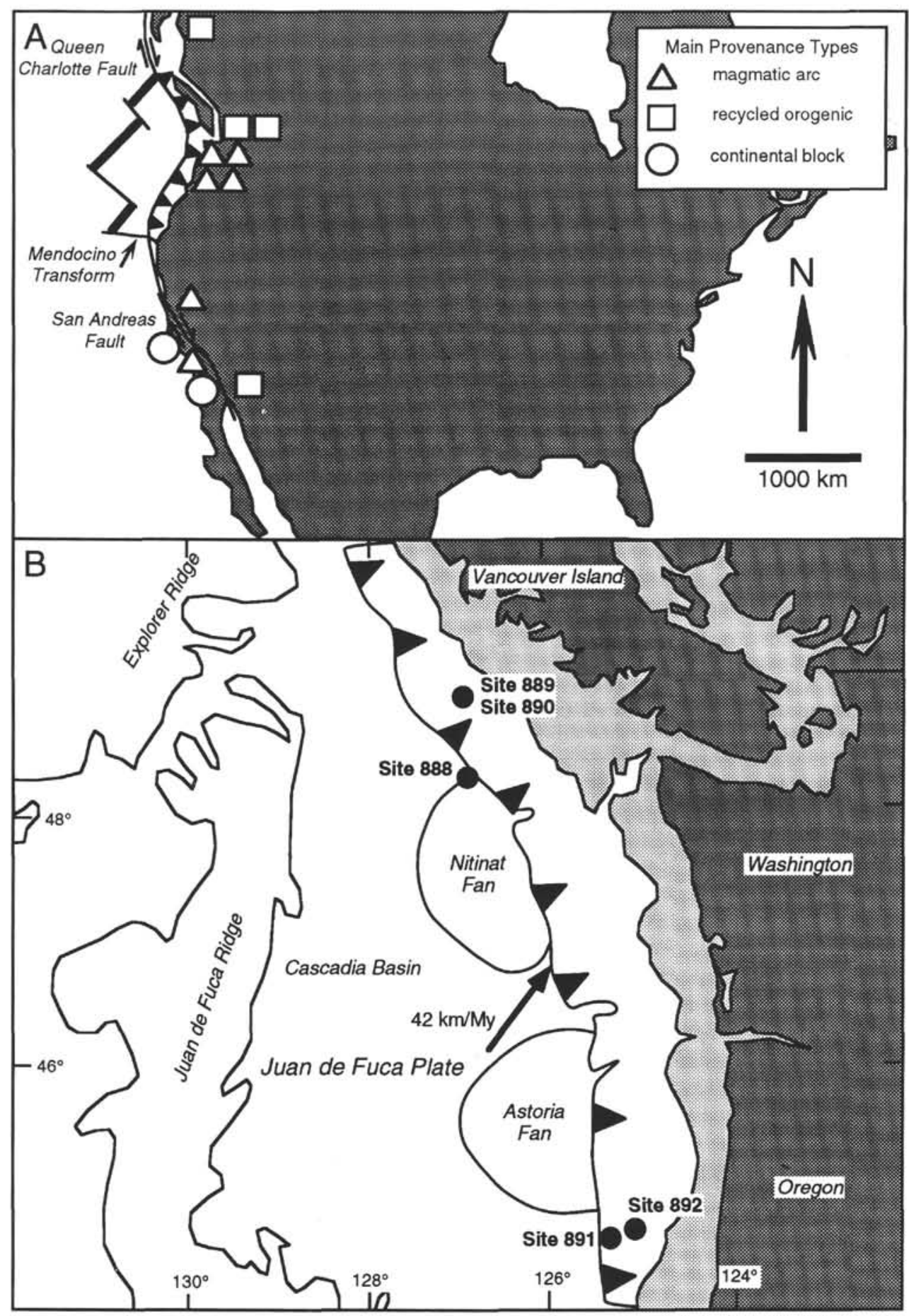

Figure 1. A. Sketch map of North America, showing plate-tectonic configuration and Neogene sandstone provenance types published in Dickinson et al. (1983). B. Location map of the Cascadia convergent margin, showing the deformation front (barbed line), the major deep-sea fans, the motion direction of the Juan de Fuca Plate relative to the North American Plate, and the positions of sites drilled during Leg 146.

subrounded, and are compositionally dominated by both feldspars. Fragments of sedimentary rocks are rarely exceed $25 \%$ of the total content of lithic fragments, and are dominated by quartz and feldspar with accessory detrital mica, pyroxene, and hornblende. Alteration of the sand fraction includes variably strong sericitization of feldspars, and chloritization of mafic minerals and volcanic lithic clasts. Most of this alteration has probably occurred in the sediment provenance area, as there is no evidence for a high-temperature diagenetic overprint in the Leg 146 sediments. The fine-grained mineral matrix is made up of variable proportions of illite, smectite, chlorite, micritic carbonate, quartz, and feldspar.

\section{SAND MODES}

The ternary QFL plot (Fig. 2) shows that sand detrital modes are moderately quartz-dominated, with slightly higher feldspar, as compared to lithic fragments. Among the sites, there is no large variation 
Table 1. List of counted grains and parameter definitions for samples analyzed from Leg $\mathbf{1 4 6}$ drill cores.

\begin{tabular}{|c|c|c|c|c|c|c|c|c|c|c|c|c|c|}
\hline $\begin{array}{l}\text { Core, section, } \\
\text { interval }(\mathrm{cm})\end{array}$ & Q & F & $\mathrm{L}$ & $\mathrm{Qm}$ & F & $\mathrm{Lt}$ & Qp & Lv & Ls & $\mathrm{Qm}$ & P & K & $\begin{array}{c}\text { Total of } \\
\text { counted } \\
\text { grains }\end{array}$ \\
\hline $\begin{array}{l}146-889 \mathrm{~A}- \\
6 \mathrm{H}-6,84-89\end{array}$ & 380 & 461 & 109 & 307 & 461 & 182 & 73 & 109 & 0 & 307 & 87 & 374 & 950 \\
\hline $\begin{array}{l}146-889 \mathrm{~B}- \\
6 \mathrm{R}-1,8-16 \\
8 \mathrm{R}-1,4-6 \\
12 \mathrm{R}-3,115-119\end{array}$ & $\begin{array}{r}30 \\
285 \\
77\end{array}$ & $\begin{array}{l}47 \\
40 \\
52\end{array}$ & $\begin{array}{r}4 \\
58 \\
23\end{array}$ & $\begin{array}{r}28 \\
227 \\
59\end{array}$ & $\begin{array}{l}47 \\
40 \\
52\end{array}$ & $\begin{array}{r}6 \\
116 \\
41\end{array}$ & $\begin{array}{r}2 \\
58 \\
18\end{array}$ & $\begin{array}{r}3 \\
58 \\
19\end{array}$ & $\begin{array}{l}1 \\
0 \\
4\end{array}$ & $\begin{array}{r}28 \\
227 \\
59\end{array}$ & $\begin{array}{r}22 \\
122 \\
6\end{array}$ & $\begin{array}{l}25 \\
83 \\
46\end{array}$ & $\begin{array}{r}81 \\
83 \\
152\end{array}$ \\
\hline $\begin{array}{l}146-891 \mathrm{~B}- \\
8 \mathrm{X}-1,2-6 \\
10 \mathrm{X}-1,49-51 \\
11 \mathrm{X}-2,2-6 \\
14 \mathrm{X}-1,66-70 \\
18 \mathrm{X}-\mathrm{CC}, 3-4 \\
32 \mathrm{X}-1,29-31 \\
32 \mathrm{X}-\mathrm{CC}, 34-39 \\
41 \mathrm{X}-1,29-35 \\
41 \mathrm{X}-1,73-79\end{array}$ & $\begin{array}{r}368 \\
1346 \\
254 \\
797 \\
269 \\
159 \\
303 \\
503 \\
374\end{array}$ & $\begin{array}{r}222 \\
507 \\
62 \\
283 \\
146 \\
150 \\
229 \\
295 \\
220\end{array}$ & $\begin{array}{r}67 \\
58 \\
63 \\
76 \\
43 \\
42 \\
146 \\
220 \\
75\end{array}$ & $\begin{array}{r}253 \\
1114 \\
192 \\
623 \\
192 \\
104 \\
220 \\
344 \\
241\end{array}$ & $\begin{array}{r}222 \\
507 \\
62 \\
283 \\
146 \\
150 \\
229 \\
295 \\
220\end{array}$ & $\begin{array}{r}182 \\
290 \\
125 \\
250 \\
120 \\
97 \\
229 \\
379 \\
208\end{array}$ & $\begin{array}{r}115 \\
232 \\
62 \\
174 \\
77 \\
55 \\
83 \\
159 \\
133\end{array}$ & $\begin{array}{r}46 \\
56 \\
59 \\
68 \\
38 \\
36 \\
128 \\
116 \\
60\end{array}$ & $\begin{array}{r}23 \\
2 \\
4 \\
8 \\
5 \\
6 \\
18 \\
104 \\
15\end{array}$ & $\begin{array}{r}253 \\
1114 \\
192 \\
623 \\
192 \\
106 \\
220 \\
344 \\
241\end{array}$ & $\begin{array}{r}90 \\
114 \\
33 \\
101 \\
40 \\
39 \\
58 \\
86 \\
57\end{array}$ & $\begin{array}{r}132 \\
393 \\
29 \\
182 \\
106 \\
111 \\
171 \\
209 \\
163\end{array}$ & $\begin{array}{r}657 \\
1911 \\
379 \\
1156 \\
458 \\
351 \\
678 \\
1018 \\
669\end{array}$ \\
\hline $\begin{array}{l}146-892 \mathrm{~A}- \\
9 \mathrm{X}-1,22-24 \\
15 \mathrm{X}-\mathrm{CC}, 20-22\end{array}$ & $\begin{array}{l}313 \\
261\end{array}$ & $\begin{array}{l}264 \\
113\end{array}$ & $\begin{array}{r}184 \\
58\end{array}$ & $\begin{array}{l}209 \\
190\end{array}$ & $\begin{array}{l}264 \\
113\end{array}$ & $\begin{array}{l}288 \\
129\end{array}$ & $\begin{array}{r}104 \\
71\end{array}$ & $\begin{array}{r}109 \\
31\end{array}$ & $\begin{array}{l}75 \\
27\end{array}$ & $\begin{array}{l}209 \\
190\end{array}$ & $\begin{array}{l}74 \\
33\end{array}$ & $\begin{array}{r}190 \\
80\end{array}$ & $\begin{array}{l}761 \\
432\end{array}$ \\
\hline $\begin{array}{l}\text { 146-892D- } \\
8 \mathrm{X}-\mathrm{CC}, 16-21\end{array}$ & 145 & 48 & 91 & 71 & 48 & 165 & 74 & 8 & 83 & 71 & 12 & 36 & 284 \\
\hline
\end{tabular}

Table 2. Percentages of counted grains and parameter definitions for samples analyzed from Leg 146 drill cores.

\begin{tabular}{|c|c|c|c|c|c|c|c|c|c|c|c|c|}
\hline $\begin{array}{l}\text { Core, section, } \\
\text { interval }(\mathrm{cm})\end{array}$ & Q & $\mathrm{F}$ & L & Qm & $\mathrm{F}$ & $\mathrm{Lt}$ & Qp & Lvm & Lsm & $\mathrm{Qm}$ & $P$ & K \\
\hline $\begin{array}{l}146-889 \mathrm{~A}- \\
6 \mathrm{H}-6,84-89\end{array}$ & 40.0 & 48.4 & 11.6 & 32.6 & 48.4 & 19.0 & 40.1 & 59.9 & 0.0 & 40.3 & 11.7 & 48.0 \\
\hline $\begin{array}{l}146-889 \mathrm{~B}- \\
6 \mathrm{R}-1,8-16 \\
8 \mathrm{R}-1,4-6 \\
12 \mathrm{R}-3,115-119\end{array}$ & $\begin{array}{l}37.0 \\
74.4 \\
50.7\end{array}$ & $\begin{array}{l}58.0 \\
10.2 \\
34.2\end{array}$ & $\begin{array}{r}5.0 \\
15.4 \\
15.1\end{array}$ & $\begin{array}{l}34.6 \\
59.0 \\
38.8\end{array}$ & $\begin{array}{l}58.0 \\
10.3 \\
34.2\end{array}$ & $\begin{array}{r}7.4 \\
30.7 \\
27.0\end{array}$ & $\begin{array}{l}33.3 \\
50.0 \\
43.9\end{array}$ & $\begin{array}{l}50.0 \\
50.0 \\
46.3\end{array}$ & $\begin{array}{r}16.7 \\
0.0 \\
9.8\end{array}$ & $\begin{array}{l}37.3 \\
85.2 \\
53.2\end{array}$ & $\begin{array}{l}29.5 \\
3.7 \\
5.44\end{array}$ & $\begin{array}{r}33.4 \\
11.1 \\
1.4\end{array}$ \\
\hline $\begin{array}{l}146-891 \mathrm{~B}- \\
8 \mathrm{X}-1,2-6 \\
10 X-1,49-51 \\
11 X-2,2-6 \\
14 X-1,66-70 \\
18 X-C \mathrm{C}, 3-4 \\
32 \mathrm{X}-1,29-31 \\
32 X-C \mathrm{C}, 34-39 \\
41 X-1,29-35 \\
41 X-1,73-79\end{array}$ & $\begin{array}{l}56.0 \\
70.5 \\
67.0 \\
68.9 \\
58.7 \\
45.3 \\
44.7 \\
49.0 \\
56.0\end{array}$ & $\begin{array}{l}33.8 \\
26.5 \\
16.4 \\
24.5 \\
31.9 \\
42.7 \\
33.8 \\
29.0 \\
33.0\end{array}$ & $\begin{array}{r}10.2 \\
3.0 \\
16.6 \\
6.6 \\
9.4 \\
12.0 \\
21.5 \\
22.0 \\
11.0\end{array}$ & $\begin{array}{l}38.5 \\
58.3 \\
50.6 \\
53.9 \\
42.0 \\
30.2 \\
32.4 \\
24.0 \\
36.0\end{array}$ & $\begin{array}{l}33.8 \\
26.5 \\
16.4 \\
24.5 \\
31.8 \\
42.7 \\
33.8 \\
29.0 \\
33.0\end{array}$ & $\begin{array}{l}27.7 \\
15.2 \\
33.0 \\
21.6 \\
26.2 \\
27.6 \\
33.8 \\
37.0 \\
31.0\end{array}$ & $\begin{array}{l}62.5 \\
80.0 \\
49.6 \\
69.6 \\
64.2 \\
56.7 \\
36.2 \\
42.0 \\
63.9\end{array}$ & $\begin{array}{l}25.0 \\
19.3 \\
47.2 \\
27.2 \\
31.7 \\
37.1 \\
55.9 \\
30.6 \\
28.8\end{array}$ & $\begin{array}{r}12.5 \\
0.7 \\
3.2 \\
3.2 \\
4.2 \\
6.2 \\
7.9 \\
27.4 \\
7.2\end{array}$ & $\begin{array}{l}53.3 \\
68.7 \\
75.6 \\
68.8 \\
56.8 \\
41.4 \\
49.0 \\
54.0 \\
52.0\end{array}$ & $\begin{array}{r}18.9 \\
7.0 \\
13.0 \\
11.2 \\
11.8 \\
15.2 \\
12.9 \\
13.0 \\
13.0\end{array}$ & $\begin{array}{l}27.8 \\
24.3 \\
11.4 \\
20.0 \\
31.4 \\
43.4 \\
38.1 \\
33.0 \\
35.0\end{array}$ \\
\hline $\begin{array}{l}146-892 \mathrm{~A}- \\
9 \mathrm{X}-1,22-24 \\
15 \mathrm{X}-\mathrm{CC}, 20-22\end{array}$ & $\begin{array}{l}41.0 \\
60.0\end{array}$ & $\begin{array}{l}35.0 \\
26.0\end{array}$ & $\begin{array}{l}24.0 \\
14.0\end{array}$ & $\begin{array}{l}27.0 \\
44.0\end{array}$ & $\begin{array}{l}35.0 \\
26.0\end{array}$ & $\begin{array}{l}38.0 \\
30.0\end{array}$ & $\begin{array}{l}36.1 \\
55.0\end{array}$ & $\begin{array}{l}37.8 \\
24.0\end{array}$ & $\begin{array}{l}26.0 \\
20.9\end{array}$ & $\begin{array}{l}44.0 \\
63.0\end{array}$ & $\begin{array}{l}16.0 \\
11.0\end{array}$ & $\begin{array}{l}40.0 \\
26.0\end{array}$ \\
\hline $\begin{array}{l}\text { 146-892D- } \\
\text { 8X-CC, 16-21 }\end{array}$ & 51.0 & 17.0 & 32.0 & 25.0 & 17.0 & 57.0 & 44.8 & 4.8 & 50.3 & 60.0 & 10.0 & 30.0 \\
\hline
\end{tabular}

in signature, so that a mixed "recycled orogenic" and "dissected arc" (Dickinson et al., 1983) sediment source appears likely for both the Vancouver and Oregon (Fig. 1) subareas of the Cascadia forearc. The QmFLt plot (Fig. 2) confirms a magmatic-arc contribution, and the approximately equal proportion of feldspar and total lithic fragments indicates that both deeply eroded batholiths and volcanics contribute to the "arc" signal. In the samples from Site 889 (Vancouver margin), quartz and feldspar domination is more distinct; this probably reflects the greater degree of uplift and exhumation of accreted continental and arc terranes in this part of the North American continental margin.

In the QmPK ternary plot (Fig. 3), the predominance of quartz and potassic feldspar points to plutonic magmatic-arc rocks and continental-block material as provenance areas. If we follow the interpretation of Dickinson and Suczek (1979) it is obvious that redeposition and maturation of the sediment in a continental margin setting imposes a major control on sediment composition. The QpLvmLsm diagram in Figure 3 shows a good correlation to the onshore outcrop patterns of the Northwestern United States as a collage of fossil subduction complexes and melange terranes. Contrary to the other discrimination plots the "Lithic" (QpLvmLsm) diagram also reveals distinct signatures for each of the drill sites, with a pronounced quartz signal on the Oregon margin, and a somewhat greater contribution of volcanic lithic fragments on the Vancouver margin.

\section{DISCUSSION}

Here, we address two points. First, we treat the question of how well the spectrum of onshore geological and tectonic units is reflected by the sand and sandstone composition in the Cascadia accretionary prism, and, in conjunction, we investigate how sandstone composition along the Cascadia margin has changed from the CretaceousTertiary to the Pleistocene-Holocene. Second, we attempt a comparison with data from other trench-forearc systems in convergent continental-margin settings. 

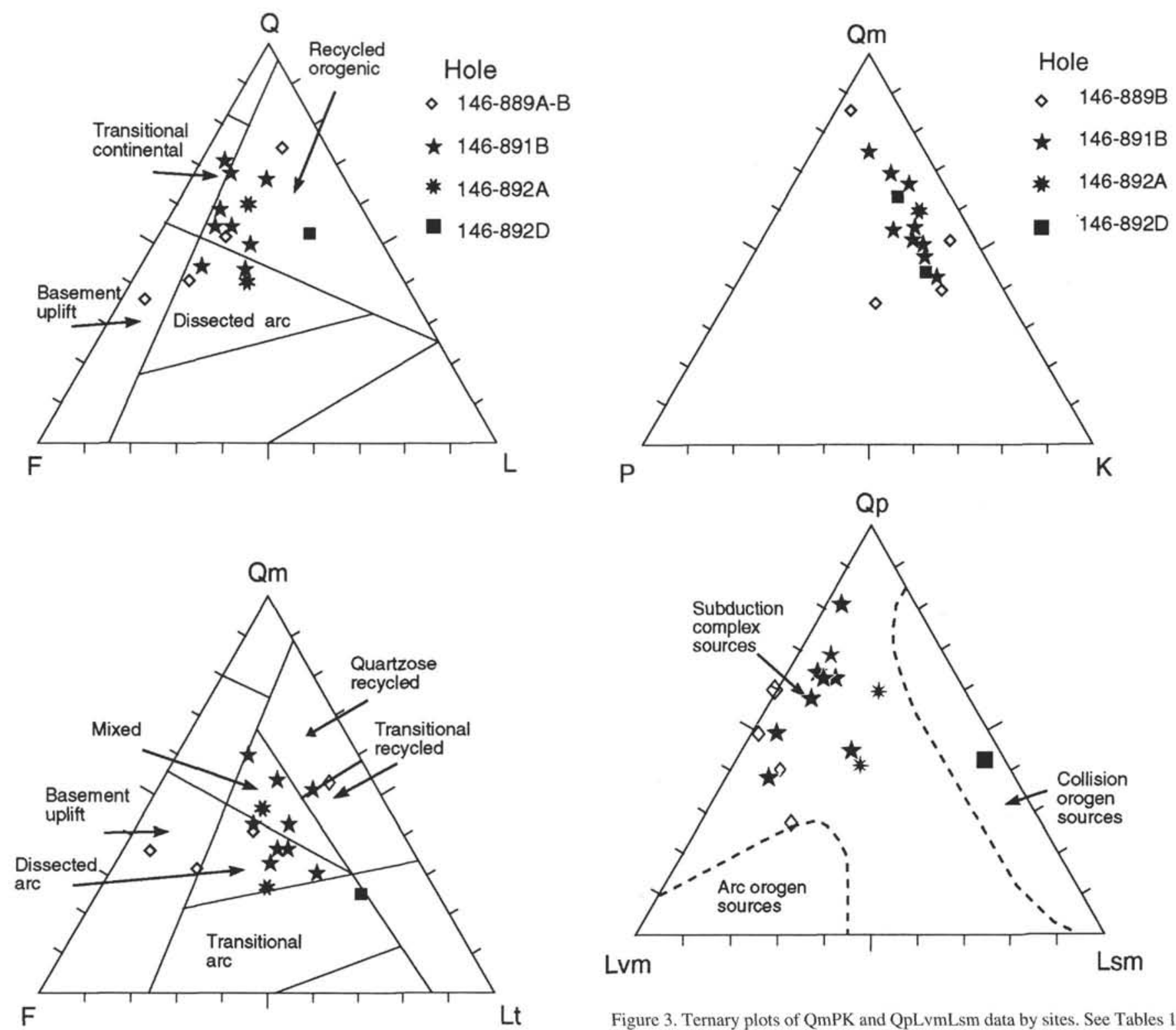

Figure 3. Ternary plots of QmPK and QpLvmLsm data by sites. See Tables 1 and 2 for parameter definitions, grains counted, and percentage values.

Figure 2. Ternary plots of QFL and QmFLt data by sites. See Tables 1 and 2 for parameter definitions, grains counted, and percentage values.

The modern provenance area of the Cascadia forearc sediments is mainly composed of felsic and intermediate magmatic and metamorphic rocks of the Columbia and Central transpressional belts of the western North American Cordillera (e.g., Oldow et al., 1989). A sizeable contribution to the sediment may be derived from the volcanics of the Tertiary Columbia River basalt province. Coastal sediments of Tertiary and Quaternary age contribute reworked material and are directly seen in the generally small fraction of sedimentary lithic fragments. The strong domination of sand mineralogy by potassic feldspar and quartz indicates that the largest contribution to the sediment probably comes from granites and granodiorites, but there may also be a contribution from rock suites typical of subduction complexes, such as the Franciscan and Olympic melange terrains (see Oldow et al., 1989).

In comparison to the Neogene sandstone suites of coastal Pacific North America analyzed by Dickinson et al. (1983), the modern Cascadia sands show slightly higher concentrations of quartz, both

monocrystalline and polycrystalline (Fig. 4). This may be interpreted as reflecting progressive uplift, exhumation, and deep erosion of the plutonic and metamorphic basement of the Columbia and Central Belts as the subducting oceanic crust of the Juan de Fuca Plate becomes younger and therefore more buoyant with time. On the other hand, our interpretation is tentative, based on few data, and should be substantiated by a more detailed analysis with better spatial and time resolution.

In comparison with data from other segments of the modern $\mathrm{Pa}-$ cific convergent margin of the Americas (Fig. 4), sand and sandstone compositions at the Peru-Chile Trench (Yerino and Maynard, 1984) and the Chile Triple Junction (Marsaglia et al., 1995) have higher feldspar percentages in general, and a stronger volcanic source signal in particular. These differences do not lend themselves to a straightforward explanation in view of the fact that both forearc-arc systems are broadly comparable in latitude, climate, and volcano-tectonic setting, and are floored by continental crust overriding a downgoing slab of comparatively young oceanic lithosphere. 


\section{SUMMARY AND CONCLUSIONS}

Quaternary terrigenous sands and sandstones from the Cascadia accretionary wedge are moderately quartz-dominated, with smaller fractions of both feldspar types and lithic fragments. The provenance area of the sediments can be characterized as "recycled-orogenic crust," with a contribution of deeply eroded magmatic-arc rocks formed above a long-lived subduction system. This description is a good reflection of the modern association of tectonic units landward of the Cascadia forearc.

\section{ACKNOWLEDGMENTS}

We are grateful for advice on sandstone petrography from many colleagues. Special thanks are due to Kathleen Marsaglia. Her review and that of Raymond Ingersoll gave us additional insights and improved the quality of the manuscript. This research was funded by Deutsche Forschungsgemeinschaft grant Be 1041/8-1 to Jan Behrmann.

\section{REFERENCES}

Dickinson, W.R., Beard, L.S., Brakenridge, G.R., Erjavec, J.L., Ferguson, R.C., Inman, K.F., Knepp, R.A., Lindberg, F.A., and Ryberg, P.T., 1983. Provenance of North American Phanerozoic sandstones in relation to tectonic setting. Geol. Soc. Am. Bull., 94:222-235.

Dickinson, W.R., and Suczek, C.A., 1979. Plate tectonics and sandstone compositions. AAPG Bull., 63:2164-2182.

Ingersoll, R.V., Bullard, T.F., Ford, R.L., Grimm, J.P., Pickle, J.D., and Sares, S.W., 1984. The effect of grain size on detrital modes: a test of the Gazzi-Dickinson point-counting method. J. Sediment. Petrol., 54:103116.

Marsaglia, K.M., 1991. Provenance of sands and sandstones from a rifted continental arc, Gulf of California, Mexico. In Fisher, R.V., and Smith, G.A. (Eds.), Sedimentation in Volcanic Settings. Spec. Publ.-Soc. Econ. Paleontol. Mineral., 45:237-248.

Marsaglia, K.M., Torres, X.V., Padilla, I., and Rimkus, K.C., 1995. Provenance of Pleistocene and Pliocene sand and sandstone, ODP Leg 141, Chile Margin. In Lewis, S.D., Behrmann, J.H., Musgrave, R.J., and Cande, S.C. (Eds.), Proc. ODP, Sci. Results, 141: College Station, TX (Ocean Drilling Program), 133-151.

Oldow, J.S., Bally, A.W., Avé Lallemant, H.G., and Leeman, W.P., 1989. Phanerozoic evolution of the North American Cordillera; United States and Canada. In Bally, A.W., and Palmer, R.A. (Eds.), The Geology of North America-An Overview: Boulder, CO (Geol. Soc. Am.), 139-232.

Westbrook, G.K., Carson, B., Musgrave, R.J., et al., 1994. Proc. ODP, Init. Repts., 146 (Pt. 1): College Station, TX (Ocean Drilling Program).

Yerino, L.N., and Maynard, J.B., 1984. Petrography of modern marine sands from the Peru-Chile Trench and adjacent areas. Sedimentology, 31:8389.

Date of initial receipt: 3 August 1994

Date of acceptance: 5 April 1995

Ms 146SR-201
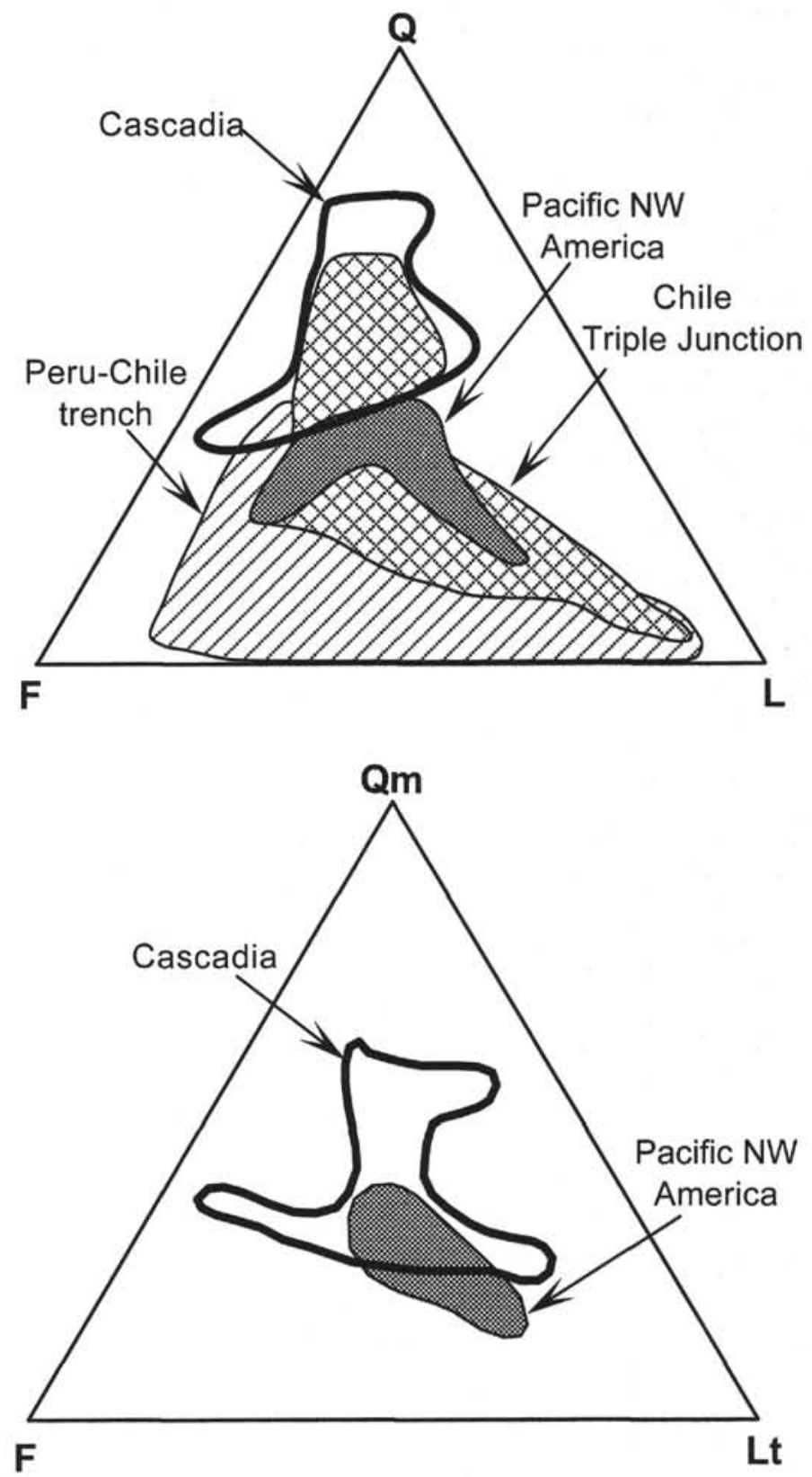

Figure 4. Ternary plots of QFL and QmFLt compositions of Cascadia sands and sandstones (this study), and sand and sandstone compositions from the U.S. Pacific Northwest (Neogene; cf. Dickinson et al., 1983), the Peru-Chile Trench (Yerino and Maynard, 1984), and the Chile Triple Junction (Marsaglia et al., 1995). See text for discussion. 